\title{
Wat heeft de bijna-arts in de opleiding geleerd over aspecten rondom het overlijden van een patiënt?
}

\author{
F. Oppewal, B. Meyboom-de Jong
}

\section{Samenvatting}

Inleiding: In het Raamplan 2001 artsopleiding komen onder meer eindtermen voor over (1) de vaststelling van een natuurlijke dood en (2) het vragen om toestemming voor orgaan- en weefseldonatie. Eerder bleek dat gevestigde huisartsen hierin weinig onderwijs hadden genoten. Wat hebben bijna-artsen in 2005 over deze eindtermen in de opleiding geleerd?

Methode: Een vragenlijst over deze items is voorgelegd aan 37 coassistenten in Groningen, die aan het eind van hun studie waren gekomen.

Resultaten: Vrijwel iedereen heeft wel een overledene gezien tijdens zijn studie. De helft heeft onderwijs gehad in het vaststellen van de dood. Slechts weinigen (3 tot 8/37) hebben onderwijs gehad in het aanvragen van obductie en donatie of het invullen van doodsoorzaakverklaringen. De juiste doodsoorzaakverklaringen (namelijk A- en B-) kon niemand aangeven. Wel wisten 29 coassistenten dat het er twee zijn. 28 coassistenten hebben een of meerdere obducties bijgewoond.

Discussie/conclusie: Waarom de opleiding niet aan deze eindtermen voldoet, is niet onderzocht. Misschien voelt niet één discipline zich specifiek verantwoordelijk voor het onderwijs in deze problematiek of zijn de eindtermen te vrijblijvend geformuleerd. Het herhaald aanbieden van onderwijs op dit terrein zou de oplossing kunnen zijn om aan de eisen van het raamplan te voldoen. (Oppewal F, Meyboom-de Jong B. Wat heeft de bijna-arts in de opleiding geleerd over aspecten rondom het overlijden van een patiënt? Tijdschrift voor Medisch Onderwijs 2006;25(4):180-184.)

\section{Inleiding}

In de opleiding tot arts komt de student geneeskunde geregeld in aanraking met kwesties rond de dood van een patiënt. De student dient hiervoor kennis en vaardigheden te ontwikkelen, naast attitudes en ethische waarden en normen, zoals in de eindtermen van de artsopleiding omschreven. ${ }^{1}$ In de eindtermen wordt onder meer gesteld dat de arts in staat moet zijn "een natuurlijke dood vast te stellen en bij vermoeden op een niet natuurlijke doodsoorzaak de juiste maatregelen te nemen" en "adequaat te handelen met betrekking tot orgaan- en weefseldonatie". ${ }^{1}$ Verder wordt verwacht dat de arts over kennis en inzicht beschikt met betrekking tot de juridische aspecten van bovengenoemde termen. ${ }^{1}$
In de problemenlijst van het Raamplan 2001 artsopleiding wordt 'acute dood' opgevoerd als een van de problemen die "iedere arts in zijn opleiding moet zijn tegengekomen (...) en die hij op een juiste manier moet kunnen aanpakken". ${ }^{1}$

Tijdens onderzoek onder praktiserende huisartsen constateerden we dat zij weinig tot geen onderwijs in genoemde aspecten hadden gekregen. ${ }^{2}$ Deze constatering was reden om na te gaan of er in de huidige opleiding iets is veranderd en verbeterd. Aan enkele coassistentgroepen hebben we gevraagd of zij gedurende hun studie onderwijs en training hadden ontvangen in deze kwesties. 
Tabel 1. Vragenlijst aspecten rondom het overlijden (met antwoorden).

1. Heb je in je leven wel eens een overledene gezien?

Zo ja, betrof het een patiënt betrof het een familielid

2. Heb je wel eens een patiënt zien overlijden? Zo ja, bij welke afdeling/stage?

3. Heb je tijdens je studie onderwijs gekregen over het vaststellen van de dood? Zo ja, tijdens het coschap ...

4. Weet je hoeveel verschillende doodsoorzaakverklaringen er in Nederland zijn?

5. Zou je de verschillende verklaringen willen noemen?

6. Heb je tijdens je opleiding een obductie bijgewoond? Zo ja, hoe vaak ... tijdens het coschap ...

7. Heb je training gehad in vragen aan familie om toestemming te geven voor obductie?

Zo ja, tijdens het coschap ...

8. Heb je training gehad in het toestemming vragen voor donororganen?

Zo ja, tijdens het coschap ...

9. Heb je onderwijs gehad in het invullen van doodsoorzaakverklaringen?

Zo ja, tijdens het coschap ...

10. Ik ben een ...

$\begin{array}{ll}\text { Ja (37) } & \text { Nee (0) } \\ \text { Ja (36) } & \text { Nee (1) } \\ \text { Ja (1) } & \text { Nee (36) } \\ \text { Ja (15) } & \text { Nee (22) }\end{array}$

$1(1) \quad 2(29) \quad 3(0)$

Ja (28) Nee (9)

Ja (4) Nee (33)

Ja (3) Nee (34)

Ja (8) Nee (29)

Vrouw (21) Man (16)

en ... jaar (23-34)

\section{Methode}

Drie willekeurig gekozen groepen coassistenten die vlak voor hun artsexamen stonden $(\mathrm{N}=37)$ en het coassistentschap huisartsgeneeskunde volgden aan de Rijksuniversiteit Groningen (RUG), hebben we een vragenlijst voorgelegd die met naam, dan wel anoniem, ingevuld en ingeleverd kon worden bij hun groepsbegeleider. De lijsten zijn in november en december 2004 ingevuld. De vragenlijst omvat vragen over de in de studie opgedane ervaringen met betrekking tot het overlijden van patiënten, het invullen van overlijdensverklaringen, het aanvragen en bijwonen van obducties en het vragen om toestemming tot orgaandonatie. De resultaten worden gepresenteerd aan de hand van de vragenlijst, die met de uitkomsten gecombineerd is tot een tabel (tabel 1), en van voorbeelden uit de antwoorden op de open vragen.

\section{Resultaten}

Alle 37 groepsleden hebben hun vragenlijst ingevuld en ingeleverd, soms voorzien van aanvullend commentaar of opmerkingen. De rechte antwoorden zijn in de tabel tussen haakjes (...) aangegeven. Zeventien respondenten gaven aan dat ze géén onderwijs hadden gekregen in het vaststellen van de dood, één wist het niet zeker. Negentien coassistenten hadden er wél onderwijs in gehad, maar op verschillende momenten in de opleiding: tijdens de keuzecursus forensische geneeskunde en een clustercursus in het eerste jaar. Enkelen vermeldden dat ze specifieke aspecten hadden geleerd, zoals het vaststellen van hersendood tijdens de stage neurologie.

Op de meerkeuzevraag over het aantal doodsoorzaakverklaringen wisten zeven respondenten geen antwoord te geven. 29 respondenten omcirkelden het (op zich 
juiste) cijfer 2. Op de open vraag naar de titels van deze verklaringen antwoordden zes respondenten met een vraagteken. Eén coassistent vulde zijn/haar antwoord aan met "acute hartdood" en "verstikking". De anderen gaven als antwoord "natuurlijke dood" en "niet-natuurlijke dood" (door acht respondenten "onnatuurlijk" genoemd). Eén respondent wist niet hoeveel verklaringen er waren, maar vulde op de open vraag als antwoord in: "natuurlijke/niet-natuurlijke dood; doodsoorzaak: CBS".

Van de 37 respondenten gaven 29 coassistenten aan dat ze géén onderwijs hadden gehad in het invullen van de doodsoorzaakverklaringen. De andere acht respondenten vulden "ja" in en noemden ook specifieke personen, zoals: privé van de assistent interne, huisarts tijdens derdejaars stage of tijdens de verpleeghuisstage.

Obducties waren bijgewoond door 28 respondenten. Dit betekent dat negen coassistenten ofwel $24 \%$ géén obductie heeft bijgewoond tijdens de studie. Eén respondent had tijdens zijn keuzecursus pathologie vijf obducties meegemaakt; de meesten vulden één of twee in, bijgewoond tijdens diverse coassistentschappen (interne, chirurgie en gynaecologie). Vier coassistenten gaven aan dat ze training hadden gehad in het vragen om toestemming voor obductie, hoewel één coassistent vermeldde: "niet echte training".

Eén van de coassistenten gaf aan twee jaar bij BIS/Eurotransplant gewerkt te hebben, maar tijdens zijn studie geen training of onderwijs genoten te hebben om toestemming te vragen voor donortransplantatie, evenals 33 van zijn collega's. Enkele respondenten antwoordden op diverse vragen dat er tijdens algemeen onderwijs aan 'alle eerstejaars co's' aandacht aan diverse onderwerpen besteed was. $\mathrm{Bij}$ de beantwoording werd aangegeven dat tijdens de facultatieve cursus forensische geneeskunde aan de onderhavige problematiek aandacht is besteed.

\section{Discussie}

Elke arts krijgt in zijn opleiding onherroepelijk te maken met het overlijden van patiënten. Aan dat overlijden zijn voor de arts formele aspecten te onderscheiden en emotionele. Enkele formele aspecten hebben we in een vragenlijst aan bijna-artsen voorgelegd. In een scriptie uit 2000 , geschreven tijdens een keuzecoschap pathologie, werd geconstateerd dat (de verschillende aspecten rond) lijkschouw een verwaarloosd gebied in de geneeskundeopleiding is. ${ }^{3}$

De antwoorden op onze vragenlijst ondersteunen deze constatering. De conclusie dat de helft (18/37) van de coassistenten aangeeft geen onderwijs te hebben gehad over het vaststellen van de dood, komt overeen met de ervaringen van afgestudeerde artsen. ${ }^{2}$ Vrijwel alle coassitenten zeggen geen onderwijs of training te hebben gehad in het omgaan met het aanvragen van toestemming voor obductie dan wel orgaandonatie. Het is bekend dat (huis)artsen weinig oog hebben voor weefseldonatie. ${ }^{4}$ Bovenstaand antwoord doet vrezen dat de komende generatie artsen hier niet veel beter voor is toegerust. Opmerkelijk is de vaststelling dat niemand de juiste namen van de beide doodsoorzaakverklaringen kan geven.

Het is aan te nemen dat deze drie groepen representatief zijn voor de opleiding aan de RUG. De vragen zijn consistent en in gelijke aantallen beantwoord. Hoe de vragenlijsten op andere opleidingen scoren kan slechts verondersteld worden; een bredere toetsing zou hiervoor de basis moeten vormen. Tegelijk zou dan ook gekeken kunnen worden of andere items uit het Raamplan 2001 artsopleiding wél een voldoende halen. 
Waarom de opleiding in deze zin niet voldoet, zou nader geanalyseerd dienen te worden. Een paar suggesties kunnen gedaan worden. Zijn de eindtermen wellicht te vrijblijvend geformuleerd? In de bijlage bij het Raamplan 2001 artsopleiding wordt bij de lijst vaardigheden het invullen van de doodsoorzaakverklaring niet vermeld. Wel wordt het aspect 'verslaglegging en registratie' genoemd. 5 De onderhavige problematiek (dood, obductie, donatie en doodsoorzaakverklaringen) komt bij verschillende disciplines aan de orde. Wellicht voelt daarom niet één afdeling zich specifiek verantwoordelijk voor dit onderdeel van de opleiding? Bekend is dat kortdurende of éénmalige training op dit terrein niet volstaat. ${ }^{6}$ Een herhaalde en intensieve probleemgeoriënteerde opleiding bij verschillende disciplines zou een basis kunnen vormen voor verbetering van de opleiding. In Nederland zijn ons enkele initiatieven bekend. De Nederlandse Transplantatie Stichting biedt een jaarlijkse basiscursus aan om achterstanden weg te nemen, zij het niet specifiek voor coassistenten. Het Nederlands Forensisch Instituut onderneemt pogingen om in de huisartsopleidingen een onderwijsblok te integreren.* In de Verenigde Staten zijn publicaties verschenen over positieve effecten van trainingen aan arts-assistenten inzake doodsoorzakenregistratie. ${ }^{7-8}$ Studieresultaten in de Nederlandse setting zijn ons niet bekend, met name niet in de geneeskundeopleiding. De enige landelijke cursus die ons bekend is, dateert uit 1998 en was bestemd voor huisartsen en verpleeghuisartsen. ${ }^{9}$

\section{Conclusie}

Vastgesteld wordt dat van de doelstellingen, zoals verwoord in het Raamplan 2001 artsopleiding, in Groningen onvoldoende aandacht besteed wordt aan de problematiek van (1) het vaststellen van een natuurlijke dood en (2) het handelen met betrekking tot orgaan- en weefseldonatie. Of de genoemde doelstellingen aan andere universiteiten wel gehaald worden, hebben we niet kunnen vaststellen. Dit zou, gezien onze resultaten, onderwerp van nader onderzoek kunnen zijn. Wij bevelen aan om in het onderwijs voorafgaand aan de coschappen aandacht te besteden aan het omgaan met het overlijden van patiënten, zodat coassistenten beter voorbereid zijn als ze hiermee geconfronteerd worden.

\section{Literatuur}

1. Metz JM, Verbeek-Weel AMM, Huisjes HJ, editors. Raamplan 2001 artsopleiding: bijgestelde eindtermen van de artsopleiding. Nijmegen: Mediagroep; 2001.

2. Oppewal F, Meyboom-de Jong B. Overwegingen van huisartsen bij het niet aanvragen van obductie; een verslag van drie focusgroepen. Ned Tijdschr Geneeskd 2003;147:1315-8.

3. Ronde I de. De lijkschouw beschouwd; een verwaarloosd gebied in de geneeskunde opleiding. Scriptie keuze co-schap pathologie. Groningen; 2000.

4. Dijk EC van, Bosman J, Groeneveld Y. Gemiste kansen, huisartsen hebben weinig oog voor weefseldonatie. Med Contact 2001;56:1803-5.

5. Metz JM, Verbeek-Weel AMM, Huisjes HJ, editors. Bijlage bij het Raamplan 2001 artsopleiding; lijst van vaardigheden, lijst van ziektebeelden. Nijmegen: Mediagroep; 2001.

6. Broer J, Wendte JF, Oei YB, Schuling J. Accurate use of death certificates. Brief training is not sufficient. Rapport GGD-Groningen. Groningen; 2002.

7. Benenson RS, Pollack ML. Evaluation of emergency medicine resident death notification skills by direct observation. Acad Emerg Med 2003;10:219-23.

8. Hobgood C, Harward D, Newton K, Davis W. The educational intervention "GRIEV-ING" improves the death notification skills of residents. Acad Emerg Med 2005;12:296-301.

9. Schouwen, dood en donatie. In: Furth WR van, Jong FR de, Vries LMA de, Schrooyen AJ, editors. Medical Didactics. Loenen aan de Vecht; 1998.

* D. Botter, schriftelijke mededeling. 


\section{De auteurs:}

Dr. F. Oppewal is huisarts.

Mw. prof. dr. B. Meyboom-de Jong is emeritus hoogleraar huisartsgeneeskunde, Rijksuniversiteit Groningen.
Correspondentieadres:

Dr. F. Oppewal, Dr. H. Brouwerstraat D7, 9663 RK

Nieuwe Pekela, f.oppewal@worldonline.nl.

Belangenconflict: geen gemeld.

Financiële ondersteuning: geen gemeld.

\section{Summary}

Introduction: 'Blueprint 2001, training of doctors in the Netherlands' sets out the national objectives of undergraduate medical education. Several objectives relate to (a) pronouncing death and (b) requesting permission for organ and tissue donation. Established general practitioners were found to have had little training in this area. We investigated what medical students nearing graduation in 2005 had learned about these issues.

Method: At University Medical Center Groningen, a questionnaire was administered to 37 medical students who were nearing graduation.

Results: Almost all of the students had seen a deceased person sometime during their training. Half of them had learned how to pronounce death. The numbers of students who had learned the proper procedures for requesting autopsy, organ donation, and completing cause of death certificates varied between three and eight. None of the students was able to correctly name the cause of death certificates (namely A- and B-), although 29 knew there were two different ones. 28 students had witnessed one or more autopsies.

Discussion/conclusion: We did not investigate the reason for not meeting the objectives of Blueprint 2001 relating to pronouncing death and requesting organ donation. Perhaps it is because no medical discipline feels responsible for providing the relevant training. Another reason may be that the terms in which the objectives are described are too general. Repeated offerings of training in these areas may help to meet these Blueprint 2001 objectives. (Oppewal F, Meyboom-de Jong B. What have near medical graduates learned about the Blueprint 2001 objectives related to patients' deaths? Dutch Journal of Medical Education 2006;25(4):180-184.) 